\title{
A Rarely Told Gloomy Saga of Resurrected Nowhere People Earlier Lived in No-man's Land
}

\author{
Debarshi Bhattacharya \\ Department of Commerce, S. R. Fatepuria College, India
}

\begin{abstract}
There were some places in independent India, where country's independence defined its people differently, resulting in creation of a separate class of 'stateless people' within Democratic India and Republic of Bangladesh. Enclaves in India and in Bangladesh were created for a variety of historical, political and geographical reasons. These were the consequence of the historical partition of India in 1947. These imminent territories within these two countries had created an inhuman situation for the people of these enclaves and enclaves' people were sustaining their existence under an inhuman situation of statelessness without support of the state aids and machineries from either country. Inhabitants of enclaves lived without proper constitutional rights and basic amenities of their livelihood till 67 years after India's independence just due to mockery of historical and political destiny. Governmental agencies of the home state couldn't get any access to these enclaves without permission of the foreign state that surrounded the enclave. Thus, inhabitants of enclaves had been unjustly becoming deprived from getting governmental services, essential facilities and basic opportunities from their mother state until signing of the historic Land Boundary agreement (LBA) between India and Bangladesh in the year 2015. Even after execution and implementation of LBA, 2015, major problematic issues of these erstwhile enclaves have not yet been resolved; nor could enclaves' people enjoy the quality of life enjoyed by their neighbours living just around these enclaves.
\end{abstract}

Keywords - Exclave, Adverse Possession, 119th Constitutional Amendment, Land Boundary Agreement (LBA), Enclaves Settlement Camps, Tin Bigha Corridor, Coochbehar District, Exchange of Enclaves.

\section{INTRODUCTION :}

On a fine morning, a country had been divided into two parts just due to political and religious interest of few people intersecting hearts of few marginal people resulting in creation of a porous border which already snatched their childhood days, their adolescent emotions, their youth courage and even their old age peaces making them isolated 'enclaves' people' only. Just only one year and half years back, there were some slivers of land in independent India and Bangladesh, where country's independence defined its people differently, resulting in creation of a separate class of 'stateless people' within these two neibouring countries. Although these people had no doubt about their own nationality; although they themselves were not at all responsible for their disgraceful destiny; yet they were forced to live in 'no-man's land' as 'nowhere people' till 67 years after India's independence just due to mockery of historical and political destiny. Enclave or exclave (Chhitmahal in Bengali) means a portion of territory of one country completely surrounded by the territory of another country (i.e. the land geographically completely separated from its mainland and fully cordoned by a foreign state). More clearly, enclave refers to a portion of territory of one state, separated from its mainland, completely surrounded by the territory of a foreign state. "From the point of view of the state in which it is located, is termed as an 'enclave' and the state to which it belongs to is an 'exclave"1". "There were 128 such Indian enclaves inside Bangladesh covering 20,95,707 acres of land and Bangladesh had its 95 enclaves inside India covering 11,00,000 acres of land". ${ }^{2}$ Later on, as per Report of the India-Bangladesh Joint Field Inspection, apart from one non-exchangeable enclave in Indian Territory, 111 exchangeable Indian Enclaves inside Bangladesh and 51 exchangeable Bangladeshi Enclaves inside India had been identified ${ }^{3}$. All these exchangeable 162 enclaves (i.e. 111 Indian Enclaves inside Bangladesh + 51 Bangladeshi Enclaves inside India) contained a total population of $53,384^{4}$. These included a few '2nd-order enclaves' or 'counter-enclave' (i.e. enclave within an enclave) as well as a '3rd-order enclave' or 'counter-counter enclave' (i.e. a Bangladeshi enclave surrounded by

1. Van Schendel, 2002: 161.

2. http://www.india-seminar.com/2002/510/510\%20urvashi\%20butalia.htm

3. Report of the India-Bangladesh Joint Field Inspection, 1996.

4. Ministry of External Affairs (MEA), "Exchange of enclaves between India and Bangladesh,” (Press Release, November 20, 2015). 
an Indian enclave, which itself surrounded by another Bangladeshi enclave). In India, all these splinters of Bangladesh were situated in the District of Coochbehar of West Bengal. On the other hand, in Bangladesh, these flakes of India were located in four Districts under its Rangpur Division, of which 59 were in Lalmonirhat District, 36 were in Ponchogarh District, 12 were in Kurigram District and 4 were in Nilphamari District ${ }^{5}$. Apart from these, there were 35 Indian Lands under Adverse Possession of Bangladesh and 42 Bangladeshi Lands under Adverse Possession of India ${ }^{6}$. There were several places along the Indo-Bangladesh Border, where the lands falling on Indian side of the demarcated International Boundary (IB) [i.e. De-jure Boundary] were actually occupied by Bangladesh (i.e. Indian land under Bangladesh occupation) and vice versa (i.e. Bangladeshi land under Indian occupation). Thus, the de-facto boundary (i.e. actual line of control) didn't not coincide with the de-jure boundary (i.e. demarcated International Boundary). Land falling between the de-jure and the de-facto boundary is called 'Adverse Possession'7. In India, these 'adverse possessions' were located in the states of Assam, Tripura, Meghalaya and West Bengal. These enclaves in India and Bangladesh were crafted for a variety of historical, political and geographical reasons. Creation of these slivers of lands in neibouring country is the consequence of the historical partition of India in 1947. These looming territories within these two countries had created an inhuman situation for the people of these enclaves and enclaves' people were sustaining their existence under a ruthless situation of statelessness without support of the state aids and machineries from either country. Inhabitants of enclaves lived year after year without proper constitutional rights and basic amenities of their livelihood. Being completely surrounded by the territory of a foreign state, they couldn't travel to their 'mother land' without crossing the territory of the foreign state and without obtaining necessary permission from the foreign state (i.e. the state that surrounded the enclave). Similarly, governmental agencies of the mother state couldn't get any access to these enclaves, despite its sovereignty over these, without permission of the foreign state that surrounded the enclave. In absence of specific international agreements between the states concerned, inhabitants of enclaves had been unjustly becoming deprived from getting governmental services, essential facilities and basic opportunities from their mother land until signing of the historic Land Boundary agreement (LBA) between India and Bangladesh in the year 2015.

\section{BACKGROUND OF THE STUDY :}

History of the enclaves accompanies a long historical tail, when Shahjahan was the mughal emperor and Raja Prananarayana was the King of Coochbehar. Raja Prananarayana occupied certain portion of territory within the Mughal Empire by defeating Mughals. Thus, the King of Coochbehar ruled over some portion of lands which were completely surrounded by lands belonging to the Mughal Empire. Similarly Mughals also wrested some portion of territory within the Coochbehar Estate which later came under the control of the Maharaja of Rangpur. ${ }^{\mathbf{8}}$. So, these lands were geographically separated from the Coochbehar and Rangpur estate, ruled by one emperor within the geographical jurisdiction of the other estate. The erstwhile Indian enclaves that now lie inside Bangladesh were once the property of the Raja of Coochbehar before India's independence. On the other hand, erstwhile Bangladeshi enclaves that now lie inside India were once the property of the Maharaja of Rangpur prior to the time of India's independence. In this context, some opine otherwise. According to an unverified popular legend, these slivers of land were used as stakes in card or chess games or other gambling centuries ago between two regional kings, the Raja of Cooch Behar and the Maharaja of Rangpur". "As per historical records, such little territories were apparently the result of a confused outcome of a 1713 treaty between the Kingdom of Coochbehar and the Mughal Empire9. Possibly, the Kingdom and the Mughals ended a war without determining a single boundary for what territories had been gained or lost.",

"In 1947, when the British finally left India after almost two centuries, they created two countries, India and Pakistan, out of one. In order to partition the country, they brought in a lawyer, Cyril Radcliffe, to demarcate the boundary between India and what was to become Pakistan, who demarcated the India-Pakistan border in straight lines cutting across territories". 10 The fact that the two States of Coochbehar and Rangpur chose not to join either India or Pakistan at the time of Independence also played a significant role in the process of creation of these enclaves. In 1949, Cooch Behar joined India and in 1952, Rangpur chose to be part of Pakistan. "What posed a problem was the fact that over the time, they had been conquering each other's territories". 11 The combined effect of all these resulted in creation of enclaves of India inside Bangladesh and vice-versa.The desire to "de-enclave" these enclaves of both the countries was firstly manifested in 1958 Agreement (NehruNoon Agreement) for exchange of enclaves between India and the then Pakistan, but the matter then hanged for

5. Report of Jugantor (2015), Bangladeshi Newspaper, August 1.

6. Report of the Faculty of Studies, BSF Academy : Surveillance \& Security of Borders, 2001.

7. Chatterjee, Shib Shankar (2011), International Border Disputes \& Adverse Possessions of India-Bangladesh Border, New Blaze.

8. https://studyacer.com/problem/chhit-mahals-of-india-and-bangladesh-2787393

9. https://en.wikipedia.org/wiki/India\%E2\%80\%93Bangladesh_enclaves

10. http://www.india-seminar.com/2002/510/510\%20urvashi\%20butalia.htm

11. Kaur, Naunidhi (2002), Frontline, Volume 19 - Issue 12, June 8-21. 
a Supreme Court case in India. With reference to said 1958 agreement, negotiations were restarted after East Pakistan became an independent country as Bangladesh in 1971. In 1974, soon after the independence of Bangladesh, The Indira-Mujib Treaty of Friendship was supposed to address three kinds of land border disputes between Bangladesh and India, who shared a 4,096.7 kms ${ }^{12}$ long porous border. Both countries mutually agreed to settle all border disputes including exchange of enclaves, status quo of adverse possession and settlement of undemarcated land boundaries between the two countries. Both countries were able to conclude the Land Boundary Agreement (LBA), 1974 (Indira-Mujib Agreement) to find an ultimate resolution to this complex nature of border demarcation. Said agreement had been implemented in its entirety, except for the three outstanding issues pertaining to ${ }^{\mathbf{1 2}}$ : (i) Exchange of enclaves; (ii) Settlement of adverse possession; (iii) Undemarcated land boundary of approximately $6.1 \mathrm{kms}$. in three sectors, viz. Daikhata-56 in West Bengal, Muhuri River-Belonia in Tripura and Lathitila-Dumabari in Assam.

As a consequence of LBA, 1974, between India and Bangladesh, India was to hand over the sovereignty of the Tin Bigha Corridor, a strip of Indian land covering an area of 178 by 85 metres $(584 \mathrm{ft} \times 279 \mathrm{ft})$ and thereby allowing access to the Dahagram-Angarpota Bangladeshi enclave ${ }^{\mathbf{1 3}}$. On the other hand, Bangladesh was to hand over the South Berubari area covering an area of 7.39 sq. kms. (2.85 sq mi). ${ }^{\mathbf{1 3}}$ Bangladesh did hand over the sovereignty of the smaller South Berubari to India instantly in 1974. India, however, could not transfer the Tin Bigha Corridor to Bangladesh till 1992, as it required constitutional amendment which could not be done due to political reasons ${ }^{13}$. Finally on 26th June, 1992, as a counterpart of the 1974 LBA package, the Tin Bigha Corridor had been leased out by India in perpetuity to Bangladesh, giving her access to Dahagram-Angorpota Enclave in order to enable her to exercise sovereignty on this twin enclave. The twin Dohogram-Angorpota Bangladeshi enclave inside Indian territory, is administrated by Patgram Upozila of Lalmonirhat District under Rangpur Division of Bangladesh and geographically located within Mekhligunj Block under Coochbehar District of West Bengal, India. Initially, the Corridor was opened for only one hour a day, which was gradually increased until 2002. In 2002, it was opened for 12 hours a day during daylight hours. On and from 19th October, 2011, the Tin Bigha Corridor remains open 24 hours a day. This 24 hours opening of Tin Bigha Corridor has brought significant changes, in the question of socio-economic, political and security status, of the people of Dohogram-Angarpota Bangladeshi Enclave. The exchange of enclaves redrawing of the international boundary and to maintain status quo of adverse possessions, India required a constitutional amendment according to Article 368 of the Constitution. Although Bangladesh ratified said agreement, but India then failed to pass necessary constitutional amendment to its Parliament to ratify said agreement. ${ }^{\mathbf{1 4}}$. In September, 2011, Governments of India and Bangladesh announced, by virtue of Monomohan-Hasina Land Boundary Agreement, an intention to resolve the issue by means of swapping 162 enclaves, giving residents a choice of nationality. As a consequence, India would have received 51 Bangladeshi enclaves inside India covering an area of 7,110.02 acres, while Bangladesh would have got 111 Indian enclaves inside Bangladesh covering an area of 17,160.63 acres. In India, the Constitution (One Hundred and Nineteenth) Amendment Bill, 2013 put forward to give effect to this proposed land exchange. But India again failed to pass necessary constitutional amendment to its Parliament to approve said agreement ${ }^{\mathbf{1 4}}$. After several postponements and delay in settlement of the destiny of people of these enclaves, their despondent sage of long almost seven decades seemed to come to an end when India ratified the Land Boundary Agreement with Bangladesh by its 119th constitutional amendment in May 2015 in both the houses of its Parliament. Immediately thereafter, aforesaid 111 Indian enclaves in Bangladesh (covering an area of 17,160.63 acres) and 51 exchangeable Bangladeshi enclaves in India (covering an area of 7,110.02 acres) ${ }^{15}$ along with 35 Indian Lands under Adverse Possession of Bangladesh (covering an area of 2267.682 acres) and 42 Bangladeshi Lands under Adverse Possession of India (covering an area of 2,777.038 acres) ${ }^{15}$ had been exchanged between the two countries by virtue of historic Land Boundary agreement (LBA) accorded between the Govt. of Republic of India and the Govt. of Peoples' Republic of Bangladesh on 6th June, 2015 with only one exception. Dohogram-Angarpota, the twin Bangladeshi Enclave situated in Mekhligunj Block under Cooch Behar District of West Bengal, India, covering a total area of 18.68 sq. kms. ${ }^{16}$ with a combined population of around 20,000, has not yet been exchanged and it still remains as an integrated part of Bangladesh, although completely surrounded by Indian Territory, as per settlement made in LBA, 1974. It is the largest Bangladeshi Enclave and is separated from the contiguous area of Bangladesh at its closest point by 178 metres (584 ft). ${ }^{17}$ As per LBA, 2015, 111 Indian enclaves in Bangladesh and 35 Indian Lands under Adverse Possession of Bangladesh henceforth be considered as own lands of Bangladesh; whereas 51 exchangeable Bangladeshi enclaves in India and 42 Bangladeshi Lands under Adverse Possession of India henceforth be

12. Land Boundary Agreement Protocol between India and Bangladesh (2011), Ministry of External Affairs, Govt. of India.

13. https://www.revolvy.com/main/index.php?s=Teen\%20Bigha\%20Corridor\&item_type=topic

14. http://self.gutenberg.org/articles/eng/Chitmahal

15. India-Bangladesh Land Boundary Agreement, 2015 (Published by Ministry of External Affairs, Govt. of India).

16. https://en.wikipedia.org/wiki/Tin_Bigha_Corridor

17. https://en.wikipedia.org/wiki/India\%E2\%80\%93Bangladesh_enclaves

DOI: 10.9790/0837-2202052332 www.iosrjournals.org 25 | Page 
considered as own lands of India. Accordingly, 51 erstwhile Bangladeshi enclaves in India and 111 erstwhile Indian enclaves in Bangladesh were physically transferred to the other country with effect from the midnight of 31 July 2015. Thus, India received 2,777.038 acres of adverse land and 7,110.02 acres of Bangladeshi enclaves' land from Bangladesh; whereas it transferred 2267.682 acres of adverse land and 17,160.63 acres Indian enclaves' land to Bangladesh. Such exchange of lands is basically a switch from a de-facto situation to a dejure one, since these enclaves and adverse possessions were already occupied by both the countries. In reality, the exchange of enclaves and adverse territories denotes a notional exchange of land, as LBA Protocol converts a de-facto reality into a de-jure situation. By virtue of LBA Protocol, people residing in these enclaves were free to choose their citizenship as per their own will. If they decided to stay in their birth soil by altering their citizenship (e.g. if a person of Indian enclave residing in Bangladesh opted to stay in Bangladesh as a Bangladeshi Citizen), they would get all benefits of citizenship of the concerned state where they opted to stay. Conversely, if they wished to migrate themselves into their mother state (e.g. if a person of Indian enclave residing in Bangladesh opted to migrate in Indian mainland), they would also get all benefits of citizenship of the concerned mother state in the concerned mainland. The concerned mother state would offer adequate rehabilitation packages to such people in its mainland. It had been highly expected from all the corners that "this long overdue exchange would endeavour to harmonize India's land boundaries and, more importantly, would improve the lives of all those residents of the enclaves who, by an unfortunate twist of fate, had been living without any national identity and without enjoying or ever knowing the quality of life enjoyed by their neighbours living just around these enclaves.",18

\section{AREA OF STUDY :}

Various erstwhile Bangladeshi Enclaves situated in Mekhligunj, Sitalkuchi, Mathabhanga and Dinhata Blocks under Coochbehar District, West Bengal, India and three Enclave Settlement Camps (Rehabilitation Camps) set up for temporary resettlement of migrated erstwhile Indian enclaves' people from Bangladesh at Haldibari, Mekhligunj and Dinhata Blocks under Coochbehar District, West Bengal, India.

\section{METHODOLOGY AND MATERIALS :}

Present study involves both primary and secondary data collected from various sources including empirical analysis of field survey data including questionnaire survey and literature survey. The data used for empirical analysis is collected from field work survey in form of personal interaction, interviews, group discussion and answers to the questionnaires, and also from Govt. reports / press releases, relevant reports of previous researchers, concerned experts' opinions, articles etc. A questionnaire containing series of effective questions had been set out to gather information from erstwhile enclaves' people, Govt. officials, representatives of erstwhile enclaves' union, public representatives, representatives of political parties, local administrative personnel, local residents around enclaves and from all other concerned persons / authorities, including previous researchers / academicians / experts in relation to the matter of undergoing study. Said field work survey had been conducted under two phases - first phase during May, 2015 (i.e. at the time of ratification of 119th Constitutional Amendment in Indian Parliament) and the second phase during June, 2016 (i.e. after execution and implementation of Land Boundary Agreement, 2015).Out of total fifty one (51) erstwhile Bangladeshi Enclaves in Indian territory, twenty (20) enclaves were chosen for field sample survey purpose during the first phase, which included large, medium and small size enclaves in Mekhligunj, Mathabhanga, Sitalkuchi and Dinhata Blocks under Coochbehar Districts of West Bengal, India. Personal interaction, group discussion, questionnaire survey had been conducted with the enclaves' people, leaders of the enclaves' union, BSF Personnel and local administration. Surveys had been conducted with all ages and genders of enclaves' people. Adequate video and still photographs were taken of the people and the location. Direct personal interactions were made with the enclaves' people. As many portion of the geographical areas within the chosen sample enclaves as possible were physically covered and examined. Cooperation from all ends was received during field work survey. During the first phase in May, 2015, twenty erstwhile Bangladeshi enclaves in Indian territory were chosen for field work survey purpose, details of which are shown below under Table -1 : 
18. Das, Rukmini \& Raju, Deepak (2013). 'A long settlement overdue”, The Hindu, August 13.

TABLE 1 : Details of Bangladeshi Enclaves visited during 1st phase of Field Work Survey

\begin{tabular}{|c|c|c|c|c|c|}
\hline $\begin{array}{l}\text { Name of erstwhile } \\
\text { Bangladeshi } \\
\text { enclaves visited }\end{array}$ & $\begin{array}{l}\text { Physically } \\
\text { located in the } \\
\text { Block of } \\
\text { Coochbehar } \\
\text { District, WB, } \\
\text { India }\end{array}$ & $\begin{array}{l}\text { Under the } \\
\text { jurisdiction } \\
\text { of Bangladeshi } \\
\text { Police } \\
\text { Station \& District }\end{array}$ & $\begin{array}{l}\text { DL } \\
\text { No. }\end{array}$ & $\begin{array}{l}\text { Area } \\
\text { in } \\
\text { acres }\end{array}$ & $\begin{array}{l}\text { Interacted } \\
\text { with No. } \\
\text { of } \\
\text { Persons in } \\
\text { the } \\
\text { enclave }\end{array}$ \\
\hline $\begin{array}{l}\text { 1. Dhabalsati } \\
\text { Mirgipur }\end{array}$ & Mekhligunj & $\begin{array}{l}\text { Patgram, } \\
\text { Lalmonirhat }\end{array}$ & 15 & 173.88 & 24 \\
\hline 2. Balapukhari & Mekhligunj & $\begin{array}{l}\text { Patgram, } \\
\text { Lalmonirhat }\end{array}$ & 21 & 331.64 & 25 \\
\hline 3. Chhit Kuchlibari & Mekhligunj & $\begin{array}{l}\text { Patgram, } \\
\text { Lalmonirhat }\end{array}$ & 22 & 370.64 & 23 \\
\hline 4. Chhit Panbari & Mekhligunj & $\begin{array}{l}\text { Patgram, } \\
\text { Lalmonirhat }\end{array}$ & 18 & 108.59 & 7 \\
\hline 5. Chhit Dhabalsati & Mekhligunj & $\begin{array}{l}\text { Patgram, } \\
\text { Lalmonirhat }\end{array}$ & 14 & 66.58 & 6 \\
\hline 6. Dhabalsati & Mekhligunj & $\begin{array}{l}\text { Patgram, } \\
\text { Lalmonirhat }\end{array}$ & 13 & 60.45 & 5 \\
\hline 7. Jotto Nijjama & Mekhligunj & $\begin{array}{l}\text { Patgram, } \\
\text { Lalmonirhat }\end{array}$ & 3 & 87.54 & 9 \\
\hline $\begin{array}{l}\text { 8. Chhit Land of } \\
\text { Kuchlibari }\end{array}$ & Mekhligunj & $\begin{array}{l}\text { Patgram, } \\
\text { Lalmonirhat }\end{array}$ & 24 & 1.83 & 0 \\
\hline $\begin{array}{l}\text { 9. Chhit Land of } \\
\text { Panbari No. } 2\end{array}$ & Mekhligunj & $\begin{array}{l}\text { Patgram, } \\
\text { Lalmonirhat }\end{array}$ & 20 & 1.13 & 0 \\
\hline 10. Bamandal & Mekhligunj & $\begin{array}{l}\text { Patgram, } \\
\text { Lalmonirhat }\end{array}$ & 11 & 2.24 & 0 \\
\hline 11. Mahishmari & Sitalkuchi & $\begin{array}{l}\text { Patgram, } \\
\text { Lalmonirhat }\end{array}$ & 54 & 122.77 & 14 \\
\hline 12. Palanpur & Sitalkuchi & $\begin{array}{l}\text { Patgram, } \\
\text { Lalmonirhat }\end{array}$ & 64 & 506.54 & 31 \\
\hline 13. Poaturkuthi & Dinhata & $\begin{array}{l}\text { Lalmonirhat, } \\
\text { Lalmonirhat }\end{array}$ & 37 & 589.94 & 32 \\
\hline $\begin{array}{l}\text { 14. Paschim Bakalir } \\
\text { Chhara }\end{array}$ & Dinhata & $\begin{array}{l}\text { Bhurungamari, } \\
\text { Lalmonirhat }\end{array}$ & 38 & 151.98 & 11 \\
\hline $\begin{array}{l}\text { 15. Madhya Bakalir } \\
\text { Chhara }\end{array}$ & Dinhata & $\begin{array}{l}\text { Bhurungamari, } \\
\text { Lalmonirhat }\end{array}$ & 39 & 32.72 & 4 \\
\hline $\begin{array}{l}\text { 16. Madhya } \\
\text { Masaldanga }\end{array}$ & Dinhata & $\begin{array}{l}\text { Bhurungamari, } \\
\text { Lalmonirhat }\end{array}$ & 3 & 136.66 & 18 \\
\hline $\begin{array}{l}\text { 17. Batrigachh I \& } \\
\text { II }\end{array}$ & Dinhata & $\begin{array}{l}\text { Kaligunj, } \\
\text { Lalmonirhat }\end{array}$ & 81 & 577.37 & 34 \\
\hline $\begin{array}{l}\text { 18. Purba } \\
\text { Masaldanga I \& II }\end{array}$ & Dinhata & $\begin{array}{l}\text { Bhurugamari, } \\
\text { Lalmonirhat }\end{array}$ & 11 & 153.89 & 14 \\
\hline $\begin{array}{l}\text { 19. Chhit Land of } \\
\text { Jagatbar No. } 3\end{array}$ & Mathabhanga & $\begin{array}{l}\text { Patgram, } \\
\text { Lalmonirhat }\end{array}$ & 37 & 69.84 & 9 \\
\hline $\begin{array}{l}\text { 20. Chhit } \\
\text { Bhanderdeha }\end{array}$ & Mathabhanga & $\begin{array}{l}\text { Patgram, } \\
\text { Lalmonirhat }\end{array}$ & 67 & 39.96 & 8 \\
\hline
\end{tabular}

Total No. of erstwhile Bangladeshi Enclaves visited in 1st phase of field work survey : 20 Total No. of persons interacted with during 1st phase of field work survey : 274

During the second phase of said field work survey, fifteen (15) erstwhile Bangladeshi enclaves in Indian territory were chosen for field sample survey purpose, which also included large, medium and small size enclaves in Mekhligunj and Dinhata Blocks under Coochbehar Districts of West Bengal, India, along with three (3) Enclave Settlement Camps (Rehabilitation Camps) set up in Haldibari, Mekhligunj and Dinhata Blocks 
under Coochbehar Districts of West Bengal, India, for resettlement of the migrated erstwhile Indian enclaves' people from Bangladesh were physically visited. Personal interaction, group discussion, questionnaire survey had been carried out with the erstwhile enclaves' people, leaders of the enclaves' union, BSF Personnel and local administration. Surveys had been conducted with all ages and genders of enclaves' people. Adequate video and still photographs were taken of the people and the location. Direct personal interactions were made with the enclaves' people. As many portion of the geographical areas within the chosen enclaves and rehab camps as possible were physically covered and examined. Cooperation from all ends was received during field work survey. During the second phase in June, 2016, fifteen erstwhile Bangladeshi enclaves in Indian territory were physically visited for field survey purpose, which are shown under

TABLE 2 : Details of Bangladeshi Enclaves visited during 2nd phase of Field Work Survey

\begin{tabular}{|c|c|c|c|c|c|}
\hline $\begin{array}{l}\text { Name of erstwhile } \\
\text { Bangladeshi } \\
\text { enclaves visited }\end{array}$ & $\begin{array}{l}\text { Physically } \\
\text { located in the } \\
\text { Block of } \\
\text { Coochbehar } \\
\text { District, WB, } \\
\text { India }\end{array}$ & $\begin{array}{l}\text { Under the } \\
\text { jurisdiction } \\
\text { of Bangladeshi } \\
\text { Police } \\
\text { Station \& District }\end{array}$ & $\begin{array}{l}\text { DL } \\
\text { No. }\end{array}$ & $\begin{array}{l}\text { Area } \\
\text { in } \\
\text { acres }\end{array}$ & $\begin{array}{l}\text { Interacted } \\
\text { with No. } \\
\text { of } \\
\text { Persons in } \\
\text { the } \\
\text { enclave }\end{array}$ \\
\hline 1. Batrigachh I \& II & Dinhata & $\begin{array}{l}\text { Kaliganj, } \\
\text { Lalmonirhat }\end{array}$ & 81 & 577.37 & 31 \\
\hline 2. Kismat Batrigachh & Dinhata & $\begin{array}{l}\text { Kaliganj, } \\
\text { Lalmonirhat }\end{array}$ & 82 & 209.95 & 15 \\
\hline $\begin{array}{l}\text { 3. Madhya } \\
\text { Masaldanga }\end{array}$ & Dinhata & $\begin{array}{l}\text { Bhurangamari, } \\
\text { Lalmonirhat }\end{array}$ & 03 & 136.66 & 07 \\
\hline $\begin{array}{l}\text { 4. Paschim } \\
\text { Masaldanga I \& II }\end{array}$ & Dinhata & $\begin{array}{l}\text { Bhurangamari, } \\
\text { Lalmonirhat }\end{array}$ & 04 & 29.49 & 06 \\
\hline 5. Poaturkuthi & Dinhata & $\begin{array}{l}\text { Lalmonirhat, } \\
\text { Lalmonirhat }\end{array}$ & 37 & 589.94 & 26 \\
\hline $\begin{array}{l}\text { 6. Dakshin } \\
\text { Masaldanga I to VI }\end{array}$ & Dinhata & $\begin{array}{l}\text { Bhurangamari, } \\
\text { Lalmonirhat }\end{array}$ & 06 & 571.38 & 33 \\
\hline $\begin{array}{l}\text { 7. Purb Masaldanga } \\
\text { I \& II }\end{array}$ & Dinhata & $\begin{array}{l}\text { Bhurangamari, } \\
\text { Lalmonirhat }\end{array}$ & 11 & 153.89 & 12 \\
\hline 8. Karala I to III & Dinhata & $\begin{array}{l}\text { Phulbari, } \\
\text { Lalmonirhat }\end{array}$ & 09 & 269.91 & 14 \\
\hline $\begin{array}{l}\text { 9. Paschim Chhit } \\
\text { Masaldanga }\end{array}$ & Dinhata & $\begin{array}{l}\text { Bhurangamari, } \\
\text { Lalmonirhat }\end{array}$ & 07 & 7.60 & 0 \\
\hline 10. Durgapur & Dinhata & $\begin{array}{l}\text { Kaliganj, } \\
\text { Lalmonirhat }\end{array}$ & 83 & 20.96 & 0 \\
\hline 11. Jotto Nijama & Mekhliganj & $\begin{array}{l}\text { Patgram, } \\
\text { Lalmonirhat }\end{array}$ & 03 & 87.54 & 10 \\
\hline 12. Srirampur & Mekhliganj & $\begin{array}{l}\text { Patgram, } \\
\text { Lalmonirhat }\end{array}$ & 08 & 1.05 & 0 \\
\hline $\begin{array}{l}\text { 13. Dhabalsati } \\
\text { Mirgipur }\end{array}$ & Mekhligunj & $\begin{array}{l}\text { Patgram, } \\
\text { Lalmonirhat }\end{array}$ & 15 & 173.88 & 18 \\
\hline 14. Balapukhari & Mekhligunj & $\begin{array}{l}\text { Patgram, } \\
\text { Lalmonirhat }\end{array}$ & 21 & 331.64 & 20 \\
\hline 15. Chhit Kuchlibari & Mekhligunj & $\begin{array}{l}\text { Patgram, } \\
\text { Lalmonirhat }\end{array}$ & 22 & 370.64 & 20 \\
\hline
\end{tabular}

Total No. of erstwhile Bangladeshi Enclaves visited in 2nd phase of field work survey : 15 Total No. of persons interacted with during 2nd phase of field work survey : 212

During said second phase of field survey in June, 2016, three (3) Rehabilitation Camps (Enclaves Settlement Camps) set up in Haldibari, Mekhligunj and Dinhata Blocks under Coochbehar Districts of West Bengal, India, for resettlement of the migrated erstwhile Indian enclaves' people from Bangladesh were also physically visited, details of which are given below as Table -3 :

TABLE 3 : Details of Rehab Camps set up for the migrated Indian Enclaves' 
people visited during 2nd phase of Field Work Survey

\begin{tabular}{|c|c|c|c|c|c|}
\hline $\begin{array}{l}\text { Name of the } \\
\text { Rehab } \\
\text { Camp } \\
\text { visited }\end{array}$ & $\begin{array}{l}\text { Physically } \\
\text { located in } \\
\text { Block \& } \\
\text { District of } \\
\text { WB, India }\end{array}$ & $\begin{array}{l}\text { No. of families } \\
\text { accommodated } \\
\text { in the camp }\end{array}$ & \begin{tabular}{|l|} 
Erstwhile \\
Indian \\
enclaves \\
wherefrom \\
they were \\
migrated
\end{tabular} & $\begin{array}{l}\text { Religion } \\
\text { of } \\
\text { Migrants }\end{array}$ & $\begin{array}{l}\text { Interacted } \\
\text { with No. } \\
\text { of persons }\end{array}$ \\
\hline $\begin{array}{l}\text { 1. Haldibari } \\
\text { Rehab } \\
\text { Camp }\end{array}$ & $\begin{array}{l}\text { Haldibari, } \\
\text { Cooch Behar }\end{array}$ & 96 & $\begin{array}{l}\text { Dohola- } \\
\text { Khagrabari, } \\
\text { Balapara- } \\
\text { Khagrabari, } \\
\text { Najirganj, Salbari }\end{array}$ & All Hindus & 45 \\
\hline $\begin{array}{l}2 . \\
\text { Mekhliganj } \\
\text { Rehab } \\
\text { Camp }\end{array}$ & $\begin{array}{l}\text { Mekhliganj, } \\
\text { Cooch Behar }\end{array}$ & 46 & \begin{tabular}{l|} 
Banskata, \\
Lotamari, \\
Kharkharia, \\
Gotamari Chhit, \\
Kajaldighi \\
\end{tabular} & $\begin{array}{l}\text { All Hindus } \\
\text { xxcept one }\end{array}$ & 31 \\
\hline $\begin{array}{l}\text { 3. Dinhata } \\
\text { Rehab } \\
\text { Camp }\end{array}$ & $\begin{array}{l}\text { Dinhata, } \\
\text { Cooch Behar }\end{array}$ & 201 & $\begin{array}{l}\text { Dohola- } \\
\text { Khagrabari, } \\
\text { Balapara- } \\
\text { Khagrabari, } \\
\text { Garati, } \\
\text { Nataktoka, } \\
\text { Daikhata, } \\
\text { Kotbhajni, } \\
\text { Beuladanga, }\end{array}$ & $\begin{array}{l}\text { Mostly } \\
\text { Hindus }\end{array}$ & 58 \\
\hline
\end{tabular}

Total No. of Rehab Camps set up for migrated erstwhile Indian Enclaves' people visited in the 2nd phase of field work survey : 03

Total No. of persons in Rehab Camps interacted with during 2nd phase of field work survey : 134

\section{Findings :}

Based on the joint survey carried out by India and Bangladesh in erstwhile enclaves of both the countries, it was evident that 989 persons, out of total 38,521 residents of erstwhile Indian enclaves in Bangladesh, opted to retain their original nationality of Indian citizenship and migrated to Indian mainland from Bangladesh ${ }^{19}$. On the other hand, all 14,863 residents of the Bangladesh enclaves in India opted for Indian nationality and opted to stay in India as Indian citizen by altering their citizenship ${ }^{19}$. It is significantly observed that not a single person from erstwhile Bangladeshi enclaves in India opted to go back to Bangladesh so far; whereas, 989 people staying at Indian enclaves in Bangladesh have already been migrated in Indian mainland. These migrated people of Indian enclaves from Bangladesh have been temporarily rehabilitated at various Enclave Settlement Camps (Rehabilitation Camp) set up in Dinhata, Mekhligunj \& Haldibari Blocks at Cooch Behar District of West Bengal.In first phase of field survey during May, 2015, 20 erstwhile Bangladeshi enclaves in Indian territory had been randomly selected on the basis of area and population of enclaves, which included 10 Bangladeshi enclaves in Mekhligunj Block, 02 Bangladeshi enclaves in Sitalkuchi Block, 06 Bangladeshi enclaves in Dinhata Block and 02 Bangladeshi enclaves in Mathabhanga Block under Coochbehar District of West Bengal, India. In this phase of field work survey, total 274 inhabitants of Bangladeshi enclaves of different age, gender and religion were interacted with, the details of them are shown below under Table - 4 :

TABLE 4 : Age and Gender-wise classification of the inhabitants of erstwhile Bangladeshi enclaves interacted with during 1st Phase of field survey :

$\begin{array}{lccc}\text { Age group of persons } & \text { Male } & \text { Female } & \text { Total } \\ \text { Above 75 years } & 18 & 06 & 24 \\ \text { Above60 to 75 years } & 25 & 14 & 39 \\ \text { Above 45 to 60 years } & 31 & 16 & 47 \\ \text { Above 30 to 45 years } & 33 & 18 & 51 \\ \text { Above 20 to 30 years } & 37 & 24 & 61 \\ \text { 10 to 20 years } & 29 & 23 & 52 \\ \text { Total } & \mathbf{1 7 3} & \mathbf{1 0 1} & \mathbf{2 7 4}\end{array}$


19. Ministry of External Affairs, Govt. of India), "Exchange of Enclaves between India and Bangladesh" (Press Release November 20, 2015).

TABLE 5 : Religion and Gender-wise classification of the inhabitants of erstwhile Bangladeshi enclaves interacted during 1st Phase of field survey :

$\begin{array}{lccc}\text { Religion-wise persons interacted } & \text { Male } & \text { Female } & \text { Total } \\ \text { Hindu } & 97 & 63 & 160 \\ \text { Muslim } & 76 & 38 & 114 \\ \text { Total } & \mathbf{1 7 3} & \mathbf{1 0 1} & \mathbf{2 7 4}\end{array}$

During second phase of field survey conducted in June, 2016, 15 erstwhile Bangladeshi enclaves in Indian territory had been randomly chosen on the basis of area and population of enclaves, which included 10 Bangladeshi enclaves in Dinhata and 05 Bangladeshi enclaves in Mekhligunj Block under Coochbehar District of West Bengal, India. In this phase of field work survey, total 212 inhabitants of erstwhile Bangladeshi enclaves of different age and gender were interacted with, the details of which are given below :

TABLE 6 : Age and Gender-wise classification of the inhabitants of erstwhile Bangladeshi enclaves interacted during 2nd Phase of field survey :

$\begin{array}{lccc}\text { Age group of persons interacted } & \text { Male } & \text { Female } & \text { Total } \\ \text { Above 75 years } & 16 & 07 & 23 \\ \text { Above60 to 75 years } & 21 & 16 & 37 \\ \text { Above 45 to 60 years } & 26 & 15 & 41 \\ \text { Above 30 to 45 years } & 28 & 20 & 48 \\ \text { Above 20 to 30 years } & 25 & 18 & 43 \\ \text { 10 to 20 years } & 13 & 07 & 20 \\ \text { Total } & \mathbf{1 2 9} & \mathbf{8 3} & \mathbf{2 1 2}\end{array}$

TABLE 7 : Religion and Gender-wise classification of inhabitants of erstwhile Bangladeshi enclaves interacted during 2nd Phase of field survey :

$\begin{array}{lccc}\text { Religion-wise persons interacted } & \text { Male } & \text { Female } & \text { Total } \\ \text { Hindu } & 74 & 49 & 123 \\ \text { Muslim } & 55 & 34 & 89 \\ \text { Total } & \mathbf{1 2 9} & \mathbf{8 3} & \mathbf{2 1 2}\end{array}$

During second phase of field survey carried out in June, 2016, three Rehabilitation Camps (Enclave Settlement Camps) set up in India for resettlements of the migrated erstwhile Indian enclaves' people from Bangladesh were also visited. These Rehab Camps were located in Haldibari, Mekhligunj and Dinhata Blocks under Coochbehar District of West Bengal, India. In these Rehab Camps, total 134 migrated inhabitants of erstwhile Indian enclaves of different age and gender were interacted with, the details of which are given below :

TABLE 8 : Age and Gender-wise classification of inhabitants of erstwhile Indian enclaves in Rehab Camps interacted with :

$\begin{array}{lccc}\text { Age group of persons } & \text { Male } & \text { Female } & \text { Total } \\ \text { Above } 75 \text { years } & 03 & 02 & 05 \\ \text { Above60 to } 75 \text { years } & 11 & 06 & 17 \\ \text { Above } 45 \text { to 60 years } & 21 & 15 & 36 \\ \text { Above } 30 \text { to } 45 \text { years } & 17 & 15 & 32 \\ \text { Above } 20 \text { to 30 years } & 18 & 15 & 33 \\ \text { 10 to 20 years } & 07 & 04 & 11 \\ \text { Total } & \mathbf{7 7} & \mathbf{5 7} & \mathbf{1 3 4}\end{array}$

TABLE 9 : Religion and Gender-wise classification of inhabitants of erstwhile Indian enclaves in Rehab Camps interacted with :

$\begin{array}{lccc}\text { Religion-wise persons interacted } & \text { Male } & \text { Female } & \text { Total } \\ \text { Hindu } & 69 & 54 & 123 \\ \text { Muslim } & 08 & 03 & 11 \\ \text { Total } & \mathbf{7 7} & \mathbf{5 7} & \mathbf{1 3 4}\end{array}$




\section{Unresolved problematic issues of the erstwhile Bangladeshi Enclaves' people who opted to stay in India :}

During said field survey, it had been observed that people of erstwhile Bangladeshi enclaves duly got their Voter ID Card and Aadhar Card in support of their Identity as Indian Citizen after implementation and execution of LBA, 2015, between India and Bangladesh, but no other problems of erstwhile Bangladeshi enclaves have yet been resolved. No infrastructural developmental works within these enclaves have been initiated so far. Two major problematic issues of the erstwhile Bangladeshi enclaves' people have been identified during field survey works. First and foremost identified problem that they are still facing with is settlement of their lands within these erstwhile enclaves. A large number of enclave dwellers anxiously brought the issue of their land settlement before us when we interacted with them during said field survey. We scrutinized that many enclave dwellers didn't possess the original title deeds of their lands issued by Bangladesh Land Settlement Authority, although all these lands were under their possessions. During long 67 years of their exiled life in enclaves, many original land deed holders already sold out their lands to other enclaves' dwellers on the basis of mutual written agreement just on a white paper. Accordingly, such transferee land occupiers do not possess original land deeds on their name, although they are occupying such lands for a number of years after such transfer took place with consideration. Now, big question is that whether such mutual written agreement just on white paper would be considered or not at the time of disposal of land records and settlements by the Govt. of India. Enclave dwellers are really afraid about settlement of their land issue, which is the only source of generating economic resources of most of enclaves' people till date. Second important identified problem of enclaves' people is job opportunity for them. No job reservation has since been made for the erstwhile enclaves' dwellers, nor has any alternative job opportunity yet been initiated for them. Even for admitting their children into an Indian School or College, enclave dwellers have still been facing lots of troubles, as no reservation has so far been made for admission of their children.

\section{Unresolved problematic issues of the migrated erstwhile Indian enclaves' people from Bangladesh :}

During said field survey, it had been studied that people of erstwhile Indian enclaves duly got their Voter ID Card and Aadhar Card in support of their Identity as Indian Citizen after resettling in Indian mainland. Govt. of India arranged temporary accommodations for them by setting up three Enclaves Settlement Camps in the District of Coochbehar, West Bengal, India, with free electricity facility and also provided essential food commodities for them through rationing system. Yet, they were scared about their permanent settlement in Indian mainland. No job reservation has since been made for these migrated erstwhile Indian enclaves' people temporarily residing at said Enclave Settlement camps; nor has any alternative job opportunity yet been initiated for them. They were feeling confused about their decision for migrating Indian mainland. In erstwhile Indian enclaves, where they lived in during last 67 years, they had their own land for cultivation and they could move to Bangladeshi land in search of their bread and butter. According to them, they can hardly get any opportunity for finding any suitable job after migrating in Indian mainland, where they are completely 'landless' as well as 'jobless'. "A year after enclave dwellers got Indian citizenship, several of these people want to go back to Bangladesh as they are miffed over the lack of job and other opportunities in India.,"20 According to PTI, "Those who have come from Indian enclaves which were situated in Bangladesh are feeling alienated here. They don't have either any job opportunities or any proper source of income. How will they secure their future? So they feel that going back to Bangladesh is the best option to secure their future. ${ }^{, 20} \mathrm{We}$ also witnessed above feelings of the migrated erstwhile Indian enclaves' people during our field survey. No permanent shelter has yet been provided to them; nor has any permanent job opportunity been procured for them so far in Indian mainland. As no reservation has since been made, migrated erstwhile Indian enclaves' people had been facing with lots of problems for admitting their children into an Indian School or College. Although, procurement of permanent shelter for the migrated erstwhile Indian enclaves' people is under process as reported by the then District Magistrate, District of Coochbehar, Mr. P. Ulganathan, IAS, while we met him in June, 2016. Mr. Ulganathan admitted that the major challenge to resolve erstwhile Bangladeshi enclaves' problem was disposal of land records and settlements. Although, he assured us that adequate funds would be released by the Govt. of India for resettlement of migrated and non-migrated erstwhile enclaves' people and infrastructural development within erstwhile enclaves.

\section{CONCLUSION :}

The imminent territory within these two countries created an inhuman situation for the co-citizen of our loving world and they were victimized for sustaining their existence in an inhuman situation of statelessness without support of the state aids just due to mockery of historical and political destiny during past 67 years. A porous political border already snatched many golden days from their lives making them just 'nowhere people' only. In 
the mean time, plenty of water has blown down the river Tista. LBA, 2015 had been accorded between the two concerned nations for settlement of this long overdue problem. Sons and daughters of Tista have started to forget their days of nightmare that they passed on. But, apart from affirmation of national citizenship identity,

20. The Indian Express (2017); "Failed promises : A year on, some enclave dwellers want to return to Bangladesh", 23rd January. no other fundamental rehabilitation program has yet been initiated by the Govt. of India for the erstwhile Bangladeshi enclaves' people till date. Neither land record and settlement problem of erstwhile Bangladeshi enclaves' people has yet been resolved; nor has any job reservation policy or alternative job opportunity yet been procured for them; nor has any educational reservation system yet been introduced for their children; nor has any infrastructural activity been set up within erstwhile Bangladeshi enclaves as yet. On the other hand, apart from issuance of Indian national identity proofs, arrangement of temporary accommodation and partial rationing system, no other permanent rehabilitation package has yet been implemented by the Govt. of India during this one and half year after signing LBA, 2015 for the migrated erstwhile Indian enclaves' people who came from Bangladesh territory. Neither any permanent shelter has yet been provided to them; nor has any job reservation policy or alternative job opportunity yet been procured for them; nor has any educational reservation system been adopted for their children as yet. In Indian enclaves inside Bangladesh where they lived earlier, they had their own land for cultivation and they could move to Bangladeshi land for seeking job opportunity; but after migrating in Indian mainland, they are completely 'landless' as well as 'jobless'. All these erstwhile enclaves' people are still feeling anxious whether 'delay in justice' would ultimately be ended with 'denial of justice' for them or not.

\section{REFERENCES :}

[1] Press Release by Ministry of External Affairs, Govt. of India (2015), "Exchange of Enclaves between India and Bangladesh".

[2] Public Diplomacy Division, Ministry of External Affairs, Govt. of India (2015), 'India Bangladesh Land Boundary Agreement'.

[3] 'Bangladesh India Land Boundary Agreement' (2011).

[4] 'Bangladesh India Land Boundary Agreement' (1974).

[5] 'PROTOCOL TO THE AGREEMENT BETWEEN THE GOVERNMENT OF THE REPUBLIC OF INDIA AND THE GOVERNMENT OF THE PEOPLE's REPUBLIC OF BANGLADESH CONCERNING THE DEMARCATION OF THE LAND BOUNDARY BETWEEN INDIA AND BANGLADESH AND RELATED MATTERS' (2011)

[6] Bill No. XV of 2013, - 'THE CONSTITUTION (ONE HUNDRED AND NINETEENTH AMENDMENT) BILL, 2013.

[7] Report of the Faculty of Studies, BSF Academy (2001), Surveillance \& Security of Borders.

[8] Report of the India-Bangladesh Joint Field Inspection (1996).

[9] Chakravarty, Pinak Ranjan (2015). 'Land Boundary Agreement - New Catalyst in Bangladesh-India Ties'. Observer Research Foundation.

[10] Dash, Jayadev (2013). 'Indo-Bangladesh Enclave Exchange : A Study with Special Reference to Human Security', http://aisc-india.in/AISC2013_web/papers/papers_final/paper_63.pdf.

[11] Chatterjee, Shib Shankar (2011). 'INTERNATIONAL BORDER DISPUTES \& ADVERSE-POSSESSIONS OF INDIABANGLADESH INTERNATIONAL BORDER', www.newsblaze.com.

[12] Cons, Jason (2014); 'Impasse and Opportunity: Reframing Postcolonial Territory at the India-Bangladesh Border', South Asia Multidisciplinary Academic Journal, http://samaj.revues.org/3791 ; DOI : 10.4000/samaj.3791.

[13] Rahaman, M Atiqur, Murshed, Md. Mahbub, Sultana Nahid (April 2013). 'Lives outside the map: the case of Angorpota-Dohogram Enclave, Bangladesh', IOSR Journal of Humanities and Social Science, IOSR Journal Of Humanities And Social Science, (IOSR-JHSS) Volume 9, Issue 1 (Mar. - Apr. 2013), PP 71-76.

[14] Ferdoush, Md. Azmeary (2014). 'RETHINKING BORDER CROSSING NARRATIVES: A COMPARISON BETWEEN BANGLADESH-INDIA ENCLAVES', Journal of South Asian Studies, http://escijournals.net/index.php/JSAS/issue/view/41.

[15] Butalia, Urvashi (2002). 'The nowhere people', http://www.india-seminar.com/2002/510.htm.

[16] Das, Rukmini \& Raju, Deepak (2013). 'A long settlement overdue', The Hindu, August 13, 2013.

[17] Report of Prothom Alo (2015), Bangladeshi Newspaper.

[18] Report of Jugantor (2015), Bangladeshi Newspaper.

[19] The Telegraph (2015), 'Borders, enclaves and progressive exchanges'.

[20] Dristhiias (2015), 'India Bangladesh Land Swap Deal and 119th Constitutional Amendment'.

[21] https://en.wikipedia.org/wiki/Tin_Bigha_Corridor

[22] https://en.wikipedia.org/wiki/India\%E2\%80\%93Bangladesh_enclaves 